\title{
Great apes in the Lake Tumba landscape, Democratic Republic of Congo: newly described populations
}

\author{
Bila-Isia Inogwabini, Bewa Matungila, Longwango Mbende, Mbenzo Abokome and Tshimanga wa Tshimanga
}

\begin{abstract}
Over 8 months we surveyed the Lake Tumba landscape, Democratic Republic of Congo, walking 86 $\mathrm{km}$ of transects and $324 \mathrm{~km}$ of reconnaissance, to document the distribution and estimate the abundance of great apes. Five separate groups of bonobo Pan paniscus were located in the areas of Bolombo-Losombo, Mbala-Donkese, Ngombe-Botuali, Botuali-Ilombe, and Mompulenge-Mbanzi-Malebo-Nguomi, and one population of chimpanzees Pan troglodytes in the BosobeleLubengo area. Mean bonobo densities ranged from 0.27 individuals $\mathrm{km}^{-2}$ in the vicinity of Lake Tumba to 2.2 individuals $\mathrm{km}^{-2}$ in the Malebo-Nguomi area. In the
\end{abstract}

latter they appear to be living at a higher density than reported for any other site. This may be due to the area's forest-savannah mosaic habitat, which may provide year-round fruit sources, with bonobos falling back on savannah fruits when forest resources are scarce. The bonobos of the Bolombo-Losombo area and the BosobeleLubengo chimpanzees have low relative abundances and live in marginal habitats of islands of terra firma within inundated forests.

Keywords Bonobo, chimpanzee, Democratic Republic of Congo, Pan paniscus, Pan troglodytes, population.

\section{Introduction}

The Lake Tumba swamps $\left(c .78,972 \mathrm{~km}^{2}\right)$ of the Democratic Republic of Congo (DRC) are among the 12 priority conservation landscapes funded by the Central African Regional Programme for the Environment of the US Agency for International Development through the International Congo Basin Forest Partnership. The site was selected as a priority conservation site in 2000 because it has biomes specific to this area (Toham et al., 2003; Burgess et al., 2004; Thieme et al., 2005; Toham et al., 2006), which is one of the most extensive swampy forests in Africa. However, despite the conservation importance of the Lake Tumba swamps, known to support at least one great ape, the Endangered bonobo Pan paniscus (Kempf \& Wilson, 1997; IUCN, 2006), and a range of other mammalian, ornithological and herpetological diversity, the area has never been properly surveyed. The little that is known concerning the presence of the bonobo is confined to the region near Lake Tumba, particularly near Botuali (Horn, 1976, 1980; Mwanza et al., 2003; Fig. 1).

Bila-Isia Inogwabini* (Corresponding author), Bewa Matungila, Longwango Mbende, Mbenzo Abokome and Tshimanga wa Tshimanga WWF-DRC Program, 15.872 Kin 1, Kinshasa, Democratic Republic of Congo. E-mail binogwabini@wwfcarpo.org

*Also at University of Kent, Canterbury, UK

Received 17 February 2006. Revision requested 2 August 2006. Accepted 14 January 2007.
The first phase of the implementation of this project was therefore to document species distributions, with a particular emphasis on bonobo, diurnal monkeys, and large herbivores such as forest buffalo Syncerus caffer nanus. This information is a prerequisite for planning effective conservation activity (Primack, 2000; Kormos et al., 2003). Furthermore, there is a need to provide up to date knowledge of great ape populations in the region because previous studies have indicated that the swampy forests of the DRC are the least represented habitat type within the country's protected area network (Inogwabini et al., 2005a,b).

The objectives of the survey were to (1) document the distribution of large mammal species of conservation concern, and (2) estimate species abundances where possible, and in relative terms where sample sizes did not permit direct estimation of density. Here we report only the information gathered on bonobo and chimpanzee Pan troglodytes. In so doing we also fill the gap identified in the prioritization of great ape populations carried out by the Great Ape Survival Project, which indicated that the knowledge of the distribution of great apes in DRC was imprecise and limited (Jackson, 2005).

\section{Study area}

About $60 \%$ of the Lake Tumba landscape (Fig. 1) is inundated and seasonally flooded forest. Depending on the season, it is home to a large mammal assemblage that includes the bonobo, chimpanzee, Angolan pied 


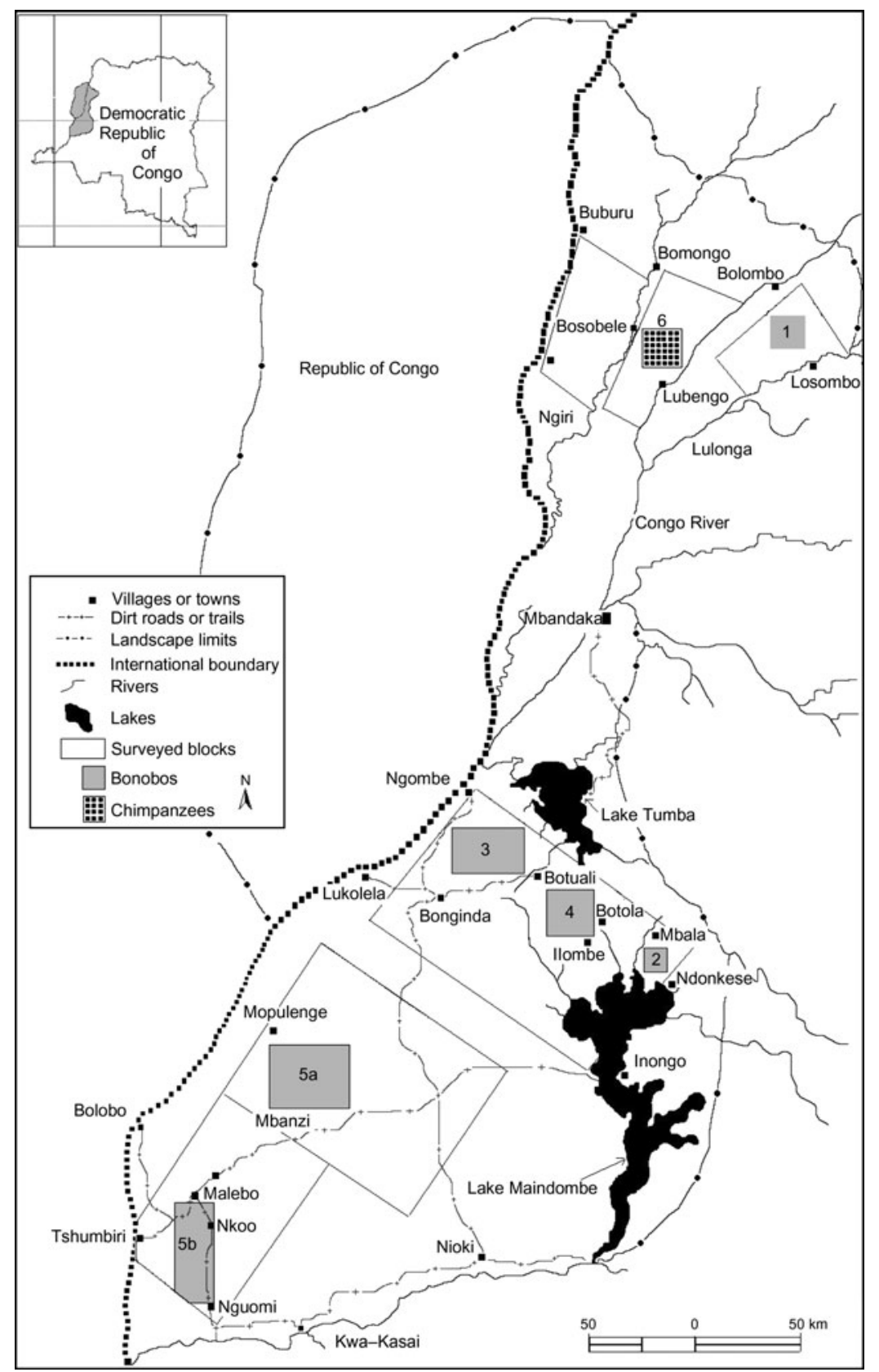

Fig. 1 Habitat blocks surveyed for great apes in the Lake Tumba area, western Democratic Republic of Congo, and the locations of the five populations of bonobo (1-5) and one population of chimpanzees (6). The limits of the Lake Tumba landscape in the main figure are indicated in the inset. colobus Colobus angolensis, Allen's swamp monkey Allenopithecus nigriviridis, black mangabey Lophocebus aterrimus, red colobus Piliocolobus tholonii, red-tailed monkey Cercopithecus ascanius, forest elephant Loxodonta africana, buffalo and leopard Panthera pardus (Marcot \& Alexander, 2004; Inogwabini, 2005). The diverse swampy biotopes have a rich diversity of fish and freshwater-dependent species such as sitatunga Tragelaphus spekei, water chevrotain Hyemoscus aquaticus, slender-snout crocodile Crocodylus cataphractus, Nile crocodile Crocodylus niloticus and hippopotamus Hippo- potamus amphibius (Toham et al., 2006). Threats to the biodiversity include increases in the local human population and logging for the wenge Mellitia laurenti (Marcot \& Alexander, 2004). Considerable unmonitored fishing occurs and bushmeat hunting is common (Authors, pers. obs.). Poaching is insidious because of the availability of weapons and ammunitions and the location of the area at the junction of major river routes (Marcot \& Alexander, 2004; Inogwabini, 2005). An additional problem is the general human poverty in the area, which adds excessive strain on natural resources through 
unplanned and unsustainable subsistence agricultural practices (Marcot \& Alexander, 2004; Inogwabini, 2005; Alexander \& Lerum, 2006).

\section{Methods}

We surveyed the area between Lake Tumba in the north and the Kwa-Kasai River in the south, bordered to the east by Lake Maindombe and to the west by the Congo River (Fig. 1). We chose this area because it is traversed by logging concessions, making knowledge of the large mammals a priority. We also surveyed areas further north, between Buburu and Bosobele, Bosobele and Lubengo, and Bolombo and Losombo (Fig. 1), where the habitats are still relatively intact.

We combined field reconnaissance (White \& Edwards, 2000) and line transect methods (Buckland et al., 1993) to collect presence/absence data (Manel et al., 2001; Ibáñez et al., 2005; Jepsen et al., 2005) and estimate abundance, respectively, during May-December 2005. Following the collection of preliminary data from two locations where $141-\mathrm{km}$ transects were cut, a total length of $86 \mathrm{~km}$ of transects were surveyed, as determined from $\mathrm{CV}(\bigoplus)=\left(b / L\left(n_{o} / l_{o}\right)\right)^{1 / 2}$, where $Ð$ is density, $b=3$, as suggested by Buckland et al. (1993) for surveys in forest, $L=$ required sampling distance in $\mathrm{km}, n_{o}=$ observations and $l_{o}=$ effort $(\mathrm{km})$ of the preliminary study, and using a coefficient of variation $\mathrm{CV}(\boxplus)$ of $10 \%$ (Buckland et al., 1993). During the surveys we collected data on nest sites, knuckle prints, feeding remains, calls, and made direct observations. Only nest sites were used to estimate population sizes. Geographical locations were determined with a global positioning system. We also made a total of $324 \mathrm{~km}$ of reconnaissance trips, on both sides of the Congo River. Apart from the logistical support team, which numbered 8-10 people depending on the length of the mission, the survey teams comprised a team leader, assistant team leader, compass bearer, and transect cutter. The team leader looked for ape nests, noted changes in habitat types, and recorded all data. The assistant team leader searched for signs on the ground such as dung, pellets and evidence of humans. The compass bearer directed the transect cutter or otherwise indicated the orientation of the reconnaissance.

To estimate bonobo density we first calculated $D$ using the software Distance v. 4.1 (Thomas et al., 2002). Distance assumes that all objects at the centre line of the transect are detected (Buckland et al., 1993) and estimates $D$ by $n$ / $\left(2^{*} L^{*} E S W\right)$, where $n=$ number of sightings, $L=$ total transect length, and ESW = effective strip width of the transect. We then used the formula of McClanahan (1986), as applied under different circumstances (Barnes et al., 1995; Hall et al., 1997), $E=D /\left(r^{*} d\right)$, where $E=$ estimated density, $D=$ density of signs, $r=$ daily rate of nest production $(=1)$, and $d=$ bonobo nest decay rate (90 days; Reinartz et al., 2006). To avoid unwarranted extrapolation of density estimates over large areas we did not incorporate areas that were unlikely to be suitable for bonobos (Inogwabini \& Omari, 2005; Reinartz et al., 2006). We did this by using the classification tool of the geographical information system ArcView v. 3.2 (ESRI, Redlands, USA) to identify open habitats (villages, savannah and large water bodies), permanent swampy forest, and young regenerating forest. At the edges of Lake Tumba we excluded the $2,874 \mathrm{~km}^{2}$ that is seasonally flooded. For the Malebo area, which comprises $1,044 \mathrm{~km}^{2}$ of mixed mature forests, $127 \mathrm{~km}^{2}$ of degraded forests and $751 \mathrm{~km}^{2}$ of savannah, we excluded savannah and degraded habitat in calculating the southernmost population. Because of small sample sizes from the edges of Lake Tumba, data from the Ngombe-Botuali and BotualiIlombe areas (Fig. 1) were pooled to estimate densities because habitats in these areas are similar. For the area of Mopulenge-Mbanzi where we did not have sufficient transect replicates to provide abundance estimates, and in the areas between Buburu and Bosobele, Bomongo and Lubengo, and Bolombo and Losombo (Fig. 1) where we had only made reconnaissance trips, we calculated encounter rates, which provide a relative indication of abundance (Strayer, 1999; Sutherland, 1999; Walsh \& White, 1999; Remis, 2000; Sutherland, 2000). Locations were plotted using ArcView, which was also used to differentiate forest types using Landsat satellite images provided by the Observatoire Satellital des Forêts d'Afrique Centrale, working in collaboration with the University of Maryland, USA and the Central African Regional Programme for the Environment.

\section{Results}

We located bonobo groups in five areas: (1) BolomboLosombo, (2) Mbala-Donkese, (3) Ngombe-Botuali, (4) Botuali-Ilombe, and (5) Mompulenge-Mbanzi-MaleboNguomi (Fig. 1). There were two sub-groups in the latter area, separated by $50 \mathrm{~km}$ of unbroken gallery forest (5a: Mopulenge-Mbanzi, 5b: Malebo-Nguomi) that may provide a link between them. One group of chimpanzees was found in the area between Bosobele and Lubengo (6). Estimates of bonobo densities and populations in sites 1, 3, 4 and $5 \mathrm{~b}$ are given in Table 1 , and nest site encounter rates of bonobos in sites 1 and $5 \mathrm{a}$ and chimpanzees in site 6 are given in Table 2 .

\section{Discussion}

The first nationwide reviews of the distribution of bonobo in the Democratic Republic of Congo, using 
Table 1 Bonobo densities and population estimates in four of the surveyed areas (numbers in Fig. 1), with size of the area surveyed and area of suitable bonobo habitat.

\begin{tabular}{|c|c|c|c|c|c|c|c|c|}
\hline \multirow[b]{2}{*}{ Location } & \multirow{2}{*}{$\begin{array}{l}\text { Area } \\
\left(\mathrm{km}^{2)}\right.\end{array}$} & \multirow{2}{*}{$\begin{array}{l}\text { Suitable } \\
\text { habitat }\left(\mathrm{km}^{2}\right)\end{array}$} & \multicolumn{3}{|c|}{ Density per $\mathrm{km}^{2}$} & \multicolumn{3}{|c|}{ Population estimate } \\
\hline & & & Lower limit & Mean & Higher limit & Lower limit & Mean & Higher limit \\
\hline 2, Mbala-Donkese & 160 & 64 & 0.24 & 0.27 & 0.29 & 15 & 17 & 19 \\
\hline 3, Ngombe-Botuali & 1,829 & 731 & 0.24 & 0.27 & 0.29 & 176 & 198 & 212 \\
\hline 4, Botuali-Ilombe & 955 & 382 & 0.24 & 0.27 & 0.29 & 92 & 103 & 111 \\
\hline 5b, Malebo-Nguomi & 1,993 & 1,044 & 1.8 & 2.2 & 3.4 & 1,880 & 2,297 & 3,550 \\
\hline
\end{tabular}

a combination of questionnaires, rapid assessment techniques and literature reviews (Fenart \& Deblock, 1973; Kano, 1984; Thompson-Handler et al., 1995), indicated that bonobo were present in 38 locations. However, only a few of these populations were confirmed by field surveys, including the 15 populations in Salonga National Park (Van Krunkelsven et al., 2000; Inogwabini \& Omari, 2005; Reinartz et al., 2006) and the populations in Wamba (Kano \& Mulavwa, 1984) and Lomako (Malenky \& Stiles, 1991; Malenky \& Wrangham, 1994; Dupain et al., 2000). In the area between Lake Tumba and Lake Maindombe (Fenart \& Deblock, 1973; Horn, 1976, 1980; Mwanza et al., 2003) available information on bonobo remained fragmentary and imprecise. Only the BotualiIlombe population (4, Fig. 1) had been previously described (Horn, 1976, 1980; Mwanza et al., 2003). Populations in the areas of Mompulenge-Mbanzi-MaleboNguomi (5, Fig. 1) were confirmed by our surveys. The popualtions we located in the Ngombe-Botuali (3, Fig. 1) and Botuali-Ilombe areas (4, Fig. 1) lie in the area of the Botanankasa-Kunungu population described by Fenart \& Deblock (1973), and the Mbala-Donkese population (2) lies in the area of the Lukolela and Tumba populations sketchily mapped by Kano (1984) and Horn (1976). The Bolombo-Losombo group (1, Fig. 1) has never been previously described.

The general pattern of the bonobo's distribution in the Lake Tumba landscape is similar to the patchy distribution of the species elsewhere (Kano, 1984; Alers et al., 1992; Inogwabini \& Omari, 2005; Kortlandt, 1995). This pattern had been attributed to a combination of ecological, historical and evolutionary factors such as major flooding, epidemics, hunting pressure, forest exploitation, food availability, topography, and forest and land use history (Badrian \& Malenky, 1984; Kano \&
Mulavwa, 1984; Sabater Pi \& Vea, 1990; Malenky \& Stiles, 1991; Malenky \& Wrangham, 1994; Kortlandt, 1995; Inogwabini \& Omari, 2005). Human history in the area may also have influenced bonobo distribution patterns. Interviews with local communities (B.-I. Inogwabini et al., unpubl. data) indicate that the Bateke people inhabiting the Malebo area believe that bonobos are their ancestors, and therefore a traditional taboo prevents the Bateke from killing bonobo

While the lower ranges of estimates of bonobo density (0.24-1.8 bonobos $\mathrm{km}^{-2}$ ) in the area south of Lake Tumba are similar to reports from other areas (Sabater Pi \& Vea, 1990; Dupain et al., 2000; Van Krunkelsven et al., 2000; Van Krunkelsven, 2001; Reinartz et al., 2006) and the encounter rate of bonobo in the Bolombo-Losombo area is lower than that in Salonga National Park (Inogwabini \& Omari, 2005; Reinartz et al., 2006), the upper limit of the density estimate in the Malebo-Nguomi area (3.4 individuals $\mathrm{km}^{-2}$ ) is probably the highest estimate ever reported. The forest-savannah mosaic of this area may provide year-round fruit sources, and thus support larger groups, with bonobos falling back on savannah fruits when forest resources are scarce. It has been estimated that there are only c. 20,000 bonobos in the wild (Caldecott \& Miles, 2005) and the mean estimate of 2,297 in the the Malebo-Nguomi area (Table 1) therefore represents $c .12 \%$ of the known wild population, making this site particularly important for the conservation of the species. We were not able to estimate density in the Mopulenge-Mbanzi area but this population is also located in a forest-savannah mosaic habitat and the high encounter rate (1.2 individuals per $\mathrm{km}$ ) may indicate that the area has a similarly high bonobo density.

The population of chimpanzees that we discovered between Bosobele and Lubengo is isolated from other

Table 2 Encounter rates for bonobos and chimpanzees in three of the surveyed areas (numbers in Fig. 1), with size of the area surveyed and area of suitable habitat.

\begin{tabular}{|c|c|c|c|c|c|}
\hline Area & Species & Area $\left(\mathrm{km}^{2}\right)$ & Suitable habitat $\left(\mathrm{km}^{2}\right)$ & Encounter rates $\left(\mathrm{km}^{-1}\right)$ & Major habitat characteristic \\
\hline 1, Bolombo-Losombo & Bonobo & 552 & 232 & 0.057 & $58 \%$ is swampy \\
\hline 5a, Mopulenge -Mbanzi & Bonobo & $1,380,390$ & 828,234 & 1.2 & Mostly savannah \\
\hline 6, Bosobele - Lubengo & Chimpanzees & 4,047 & 1,923 & 0.019 & $52 \%$ is swampy \\
\hline
\end{tabular}


known chimpanzee populations and inhabits a swampy habitat with dominant vegetation consisting of Pandanus sp. and Raffia sese that is markedly different from the described habitat type of this species. The encounter rate of chimpanzee signs (0.019 nest sites $\left.\mathrm{km}^{-1}\right)$ was lower than in either the Kahuzi-Biega National Park in eastern DRC (Inogwabini et al., 2000) or Luki in western DRC (Lomboto, 2007). Chimpanzees are the least documented great apes in DRC (Hart \& Hall, 1996; Hall et al., 1998; Omari et al., 1999; De Merode et al., 2000; Inogwabini et al., 2000), with precise information available only for populations in Ituri (Hart \& Hall, 1996), the KahuziBiega National Park (Inogwabini et al., 2000), and the Itombwe forest (Omari et al., 1999). The conservation status of chimpanzee in DRC is similar to that of the species across its range, with populations having decreased in the last 5 decades (Butynski, 2003; Kormos et al., 2003; Kormos \& Boesch, 2003). Therefore, despite an apparently low abundance as determined from the encounter rate, the chimpanzee population of the Bosobele-Lubengo area warrants a more detailed survey.

The discovery of both bonobo and chimpanzee in areas where they had not been previously described is good news for the conservation of these species. The bonobo were located in an area that extends the known range of the species further west. The high density estimates in a habitat type that would appear to be marginal suggests that extrapolations of abundance of this species based on habitat modelling (Kortlandt, 1995) need to be revised, and that only field surveys can provide realistic estimates. Furthermore, the discovery of this population in a savannah-forest mosaic habitat necessitates further ecological and ethological studies as the population may have adapted behaviours that have not been previously documented.

\section{Acknowledgements}

This publication was made possible through financial support provided by the US Agency for International Development through the Central African Regional Environmental Program-Congo Basin Forest Partnership. The authors' views expressed in this publication do not necessarily reflect the views of the United States Agency for International Development or the United States Government. We would like to thank the DRC Government for permission to work in the Lake Tumba landscape. We thank the WWF National and Central African Regional coordination for unfailing support to the Lake Tumba project. The research was designed at the University of Kent under the supervision of Professor Nigel Leader-Williams. Constructive comments from two anonymous reviewers helped improve the paper.

\section{References}

Alers, M.P.T., Blom, A., Sikubwabo, K., Masunda, T. \& Barnes, R.F.W. (1992) Preliminary assessment of the status of forest elephants in Zaire. African Journal of Ecology, 30, 279 ?291.

Alexander, R. \& Lerum, J. (2006) Development of a Community Use Zone Planning Framework, Lac Tumba Landscape, Democratic Republic of Congo. USDA Forest Service Technical Assistance Mission, 8-29 November 2005. Trip Report for International Programs Office, USDA Forest Service, Washington, DC, USA.

Badrian, N.L. \& Malenky, R.K. (1984) Feeding ecology of Pan paniscus in the Lomako forest, Zaire. In The Pygmy Chimpanzee: Evolutionary Biology and Behavior (ed. R.L. Susman), pp. 325-346. Plenum Press, New York, USA.

Barnes, R.F.W., Blom, A., Alers, M.P.T. \& Barnes, K.L. (1995) An estimate of the numbers of forest elephants in Gabon. Journal of Tropical Ecology, 11, 27-37.

Buckland, S.T., Anderson, D.R., Burnham, K.P. \& Laake, J.L. (1993) Distance Sampling: Estimating Abundance of Biological Populations. Chapman and Hall, London, UK.

Burgess, N., D'Amico, J.H., Underwood, E., Dinerstein, E., Olson, D.M., Itoua, I., Shipper, J., Ricketts, T.H. \& Newman, K. (eds) (2004) The Terrestrial Ecoregions of Africa and Madagascar. Island Press, Washington, DC, USA.

Butynski, T.M. (2003) The robust chimpanzee Pan troglodytes: taxonomy, distribution, abundance and conservation status. In West African Chimpanzees: Status Survey and Conservation Action Plan (eds R. Kormos, C. Boesch, M.I. Bakkar \& T.M. Butynski), pp. 5-11. IUCN/Species Survival Commission Primate Specialist Group, IUCN, Cambridge, UK.

Caldecott, J. \& Miles, L. (eds) (2005) World Atlas of Great Apes and their Conservation. University of California Press, Berkeley, USA.

De Merode, E., Hillman-Smith, K., Nicholas, A., Ndey, A. \& Likango, M. (2000) The spatial correlates of wildlife distribution around Garamba National Park, Democratic Republic of Congo. International Journal of Remote Sensing, 21, 2665-2683.

Dupain, J., Van Krunkelsven, E., Van Elsacker, L. \& Vereheyen, R.R. (2000) Current status of bonobo (Pan paniscus) in the proposed Lomako reserve (Democratic Republic of Congo). Biological Conservation, 94, 265-272.

Fenart, R. \& Deblock, R. (1973) Pan paniscus et Pan troglodytes: craniométrie - étude comparative et ontogénique selon les méthodes classiques et vestibulaires. Tome 1, Musée Royal de l'Afrique Centrale, Tervuren, Belgium.

Hart, J.A. \& Hall, J.S. (1996) Status of Eastern Zaire's forest parks and reserves. Conservation Biology, 2, 316?327.

Hall, J.S., Inogwabini, B.I., Williamson, E.A., Omari, I., Sikubwabo, C. \& White, L.J.T. (1997) A survey of elephants (Loxodonta africana) in the Kahuzi-Biega National Park lowland sector and adjacent forest in eastern Zaire. African Journal of Ecology, 35, 213-223.

Hall, J.S., White, L.J.T., Inogwabini, B.I., Omari, I., Morland, H.S., Williamson, E.A., Walsh, P., Sikubwabo, C., Saltonstall, K., Dumbo, B., Kiswele, K., Vedder, A. \& Freeman, K. (1998) A survey of the Grauer's gorilla (Gorilla gorilla graueri) and eastern chimpanzee (Pan troglodytes schweinfurthi) in the Kahuzi-Biega National Park lowland sector and adjacent forests in Eastern Democratic Republic of Congo. International Journal of Primatology, 19, 207-235.

Horn, A.D. (1976) A preliminary report on the ecology and behavior of the bonobo chimpanzee (Pan paniscus Schwarz 1929) and 
a reconsideration of the evolution of the chimpanzee. $\mathrm{PhD}$ thesis, Yale University, New Haven, USA.

Horn, A.D. (1980) Some observations on the ecology of the bonobo chimpanzee (Pan paniscus Schwarz 1929) near Lake Tumba, Zaire. Folia Primatologica, 34, 145-169.

Ibáñez, J.J., Caniego, J. \& Garciá-Álvarez, A. (2005) Nested subset analysis and taxa-range size distributions of pedological assemblages: implications for biodiversity studies. Ecological Modelling, 182, 239-256.

Inogwabini, B.I. (2005) Preliminary Conservation Status of Large Mammals in the Lac Tumba - Lac Mai-Ndombe Hinterland, with Emphasis on Identification of Biologically Important Zones. Report submitted to WWF-US as an annual report to the CARPE-USAID Programme.

Inogwabini, B.I., Hall, J.S., Vedder, A., Curran, B., Yamagiwa, J. \& Basabose, K. (2000) Conservation status of large mammals in the mountain sector of Kahuzi-Biega National Park, Democratic Republic of Congo in 1996. African Journal of Ecology, 38, 269-276.

Inogwabini, B.I. \& Omari, I. (2005) A park-wide distribution of Pan paniscus in the Salonga National Park, Democratic Republic of Congo. Endangered Species Update, 22, 116-123.

Inogwabini, B.I., Omari, I. \& Mbayma, A.G. (2005) Protected Areas of the Democratic Republic of Congo. Conservation Biology, 19, 15-22.

Inogwabini, B.I., Omari, I., Mbayma, A.G. \& Zasy, N.G. (2005) Protected areas of the Democratic Republic of Congo: a habitat gap analysis to guide the extension of the network. Endangered Species Update, 22, 71-82.

IUCN (2006) 2006 IUCN Red List of Threatened Species. IUCN, Gland, Switzerland [http://www.redlist.org, accessed 19 February 2007].

Jackson, W. (2005) Rapport de la première réunion intergouvernementale sur les grands singes et sur le projet pour la survie des grands singes (GRASP) et première réunion du conseil du GRASP - Kinshasa, République Démocratique du Congo (5 - 9 septembre 2005). UNESCO, Paris France.

Jepsen, J.U., Baveco, J.M., Topping, C.J., Verboom, J. \& Vos, C.C. (2005) Evaluating effect of corridors and landscape heterogeneity on dispersal probability: a comparison of three spatially explicit modeling approaches. Ecological Modelling, 181, 445-459.

Kano, T. (1984) Distribution of pygmy chimpanzees (Pan paniscus) in the central Zaire basin. Folia Primatologica, 43, 36-52.

Kano, T. \& Mulavwa, M. (1984) Feeding ecology of the pygmy chimpanzees (Pan paniscus) of Wamba. In The Pygmy Chimpanzee: Evolutionary Biology and Behaviour (ed. R.L. Susman), pp. 233-274. Plenum Press, New York, USA.

Kempf, E. \& Wilson, A. (1997) Les grands singes dans la natureRapport du WWF sur le statut des espèces. WWF, Gland, Switzerland.

Kormos, R., Bakkar, M.I., Bonnéhin, L. \& Hanson-Alp, R. (2003) Bushmeat as a threat to chimpanzees in West Africa. In West African Chimpanzees: Status Survey and Conservation Action Plan (eds R. Kormos, C. Boesch, M.I. Bakkar \& T.M. Butynski), pp. 151-155. IUCN/Species Survival Commission Primate Specialist Group, Cambridge, UK.

Kormos, R. \& Boesch, C. (eds) (2003) Regional Action Plan for the Conservation of Chimpanzees in West Africa. IUCN, Cambridge, UK.

Kortlandt, A. (1995) A survey of the geographical range, habitats and conservation of the pygmy chimpanzee (Pan paniscus): ecological perspective. Primate Conservation, 16, 21-36.
Lomboto, M. (2007) Rapport de mission sur les inventaires fauniques realizes dans la concession forestière de FORABOLA au Bas-Congo. Report submitted to WWF-DRC, Democratic Republic of Congo.

Malenky, R.K. \& Stiles, E.W. (1991) Distribution of terrestrial herbaceous vegetation and its consumption by Pan paniscus in the Lomako forest, Zaire. American Journal of Primatology, 23, $153-169$.

Malenky, R.K. \& Wrangham, R.W. (1994) The relative importance of terrestrial herbs for bonobos and chimpanzees: comparative data from Lomako and Kibale. Bulletin of Chicago Academy of Science, 15, 7.

Manel, S., Williams, H.C. \& Ormerod, S.J. (2001) Evaluating presence-absence models in ecology. Journal of Applied Ecology, 38, 921-931.

Marcot, B.G. \& Alexander, R. (2004) Exploratory trip to Democratic Republic of the Congo, August 20-September 15, 2004. Report for International Programs Office, USDA Forest Service, Washington, DC, USA.

McClanahan, T.R. (1986) Quick population survey method using faecal droppings and the steady state assumption. African Journal of Ecology, 24, 37-39.

Mwanza, N., Mulavwa, M., Ihomi, M. \& Kumugo, Y. (2003) Confirmation of bonobo population around Lake Tumba. Pan Africa News, 10, 29.

Omari, I., Hart, J.A., Butynski, T.M., Birhashirwa, N.R., Upoki, A., M'keyo, Y., Bashonga, M. \& Bagurubumwe, N. (1999) The Itombwe Massif, Democratic Republic of Congo: biological surveys and conservation, with emphasis on Grauer's gorilla and birds endemic to the Albertine Rift. Oryx, 33, 301-322.

Primack, R.B. (2000) A Primer for Conservation Biology, 2nd edition. Sinauer Associates, Sunderland, USA.

Reinartz, G., Inogwabini, B.I., Mafuta, N. \& Lisalama, W.W. (2006) Effects of forest type and human presence on bonobo (Pan paniscus) density in the Salonga National Park. International Journal of Primatology, 27, 603-634.

Remis, M.J. (2000) Preliminary assessment of the impact of human activities on gorillas. Oryx, 34, 56-66.

Sabater Pi, J. \& Vea, J.J. (1990) Nest building and population estimates of the Bonobo from the Lofeke-Lilungu-Ikomaloki region of Zaire. Primate Conservation,11, 43-48.

Strayer, D.L. (1999) Statistical power of presence-absence data to detect population declines. Conservation Biology, 13, 1034-1038.

Sutherland, W.J. (1999) Ecological Census Techniques: A Handbook. Cambridge University Press, Cambridge, UK.

Sutherland, W.J. (2000) The Conservation Handbook: Research, Management and Policy. Blackwell Science, Oxford, UK.

Thieme, M.L., Abell, R.A., Stiassny, M.L.J., Skelton, P.H., Lehner, B., Teugels, G.G., Dinerstein, E., Toham, K.A., Burgess, N. \& Olson, D.M. (eds) (2005) Freshwater Ecoregions of Africa: A Conservation Assessment. Island Press, Washington, DC, USA.

Thomas, L., Buckland, S.T., Burnham, K.P., Anderson, D.R., Laake, J.L., Borchers, D.L. \& Strindberg, S. (2002) Distance sampling. Encyclopedia of Environmetrics, 1, 544-552.

Thompson?Handler, N., Malenky, R. \& Reinartz, G.E. (1995) Action Plan for Pan paniscus? Report on Free Ranging Populations and Proposals for their Preservation. Zoological Society of Milwaukee, Wisconsin, USA.

Toham, K., Adeleke, A.W., Burgess, N.D., Carroll, R., D'Amico, J.Dinerstein, E., Olson, D.M. \& Some, L. (2003) Forest conservation in the Congo Basin. Science, 299, 346. 
Toham, K.A., D'Amico, J., Olson, D.M., Blom, A., Trowbridge, L., Burgess, N., Thieme, M., Abell, R., Carroll, R.W., Gartlan, S., Langrand, O., Mussavu, R.M., O'Hara, D. \& Strand, H. (eds) (2006) A Vision for Biodiversity Conservation in Central Africa: Biological Priorities for Conservation in the Guinean-Congolian Forests and Freshwater Region. WWF, Washington, DC, USA.

Van Krunkelsven, E. (2001) Density estimation of bonobos (Pan paniscus) in Salonga National Park, Congo. Biological Conservation, 99, 387-391.

Van Krunkelsven, E., Inogwabini, B.I. \& Draulans, D. (2000) A survey of bonobos and other large mammals in the Salonga National Park, Democratic Republic of Congo. Oryx, 34, 180-187.

Walsh, P.D. \& White, L.J.T. (1999) What it will take to monitor forest elephant populations. Conservation Biology, 13, 1194-1202.

White, L.J.T. \& Edwards, A. (2000) Methods for assessing the status of animal populations. In Conservation Research in the African Rain Forests: A Technical Handbook (eds L.J.T. White \& A. Edwards), pp. 218-268. Wildlife Conservation Society, New York, USA.

\section{Biographical sketches}

Bila-Isia Inogwabini's work has included surveys of Grauer's gorilla, eastern chimpanzees and forest elephant in the eastern Democratic Republic of Congo (then Zaire). He commenced his research on bonobos in 1997, and between 2002 and 2004 contributed to the region-wide elephant survey initiated by CITES under its programme for the monitoring of illegal killing of elephants (MIKE). He now coordinates the WWF project in the Lake Tumba landscape. Bewa Matungila, Longwango Mbende and Mbenzo Abokome were team leaders for the region-wide elephant survey initiated by CITES under its MIKE programme. They joined the WWF's Lake Tumba Project in 2005 where they are in charge of the monitoring of large mammals. Tshimanga wa Tshimanga joined WWF's Lake Tumba Project in 2005 as the project's GIS officer. 